\title{
Physicochemical Characterization and Antibacterial and Antifungal Activities of Pistacia lentiscus Oil in Northeastern Algeria
}

\author{
Moncef Beldi1", Abdennour Boucheker ${ }^{1,2}$, Radia Djelloul1 and Amel Lazli1 \\ ${ }^{1}$ Labratory of Functional and Evolutionary Ecology, Department of Biology, Faculty of Science of Nature \\ and Life, Chadli Bendjedid University, BP:73 - 36000 El Tarf, Algeria \\ ${ }^{2}$ Laboratory of Wetlands Conservation (L.C.Z.H), University May 8, 1945 Guelma, BP 401, \\ 24000 Guelma, Algeria
}

\begin{abstract}
The aim of this study is to validate the importance of Pistacia lentiscus, a species very widespread in northeastern Algeria, locally called "Dharou" as multipurpose pharmaceutical potential. Due to its richness in chemical components, it has been known for decades and widely used in the Arab and European pharmacopoeia in traditional medicine. In Algeria, this medicinal plant is mainly known and used in rural areas. Depending on the part of the plant, it is used to treat different diseases such as stomach ulcers, cough, diarrhea, bronchitis, burns, and eczema. To realize this study, we collected samples of lentisk oils traditionally extracted by the rural populations of seven regions, on which physicochemical analyzes (color, humidity, acidity index, peroxide index, phosphatide, saponification index) was carried out. The physicochemical parameters of oil collected were values corresponded to the international standards and generally reflecting a fairly oil's good quality, with the exception of the acidity index values, that exceeded standards in five regions. Exploring and evaluating their antibacterial and antifungal activities, using wells technique in order to determine the minimum inhibitory concentrations (MIC), were also done. The bacterial pathogens used were Pseudomonas aeruginosa, Staphylococcus aureus and Kelbsiella pneumonia. Meanwhile, for antifungal activity, the fungal strains tested were: Verticillium $s p$, Pythium $s p$ and Phytophthora sp. All oils samples were ineffective against the bacterial strains tested. In contrary, antifungal activities were observed, suggesting that these oils can be used for biological control of fungi growth in various types of crops. Despite the exceptional medicinal virtues of Pistacia lentiscus in the Maghreb region, few studies have been devoted to this plant, which gives even more interest to our study.
\end{abstract}

Keywords: Antibacterial activity, Antifungal activity, Oil, Pistacia lentiscus, Physicochemical parameters.

\section{INTRODUCTION}

Algeria has a remarkable flora richness estimated at nearly 4000 taxa (Miara et al., 2018). However, the medicinal flora has fading shadow with few studies on their importance (Baba Aissa, 2000; Hamel et al., 2018). Among these medicinal plants listed, there is Pistatia lentiscus, an evergreen shrub of the Anacardiaceae family which is commonly dispersed in Algeria over the entire littoral. It is well known as "mastic tree" and has dark green leaves, with distinctive strong smell. The fruits are reddish-black berries when entirely ripen (Photo 1). From these edible ripen fruits is extracted an oil that was once commonly used in traditional medicine by rural populations. The phytochemical components of these fruits include tannins, essential oils, vitamins, flavonoids, etc. (Hamlat and Hassani, 2008).

Historically, the use of the plant and its oil made our ancestors know many of its virtues. Not so long ago, the branches and leaves of Lentisk were used to clean terracotta utensils. Nowadays, its oil is known for its many therapeutic benefits, especially on the respiratory tract and its aseptic properties. On both sides of the Mediterranean shores, traditional medicines attribute virtues to this plant in the treatment of ulcers, hypertension, cough, sore throat, eczema, kidney stones and jaundice (Gardeli et al., 2008; GonzalezTejero et al., 2008; Ouelbani et al., 2016; Bouasla and Bouasla, 2017, Senouci et al., 2019).

Depending on the local region, Pistacia lentiscus fruit oil is often used as an external remedy applied locally as an ointment to treat burns (Bensegueni, 2007) or back pain (Bellakhdar, 1997). It is also used orally for respiratory problems of allergic origin and stomach ulcers (Miara et al., 2018; Senouci et al., 2019). In most of the rural localities where this plant grows, the production of its oil, which is based on purely traditional methods, is carried out by women (Djedaia, 2017; Lazli et al., 2019; Senouci et al., 2019). This undeniably lucrative activity has, however, opened up new horizons for other local populations, who have begun to produce at a more business-oriented production rate. Several actions have been carried out to increase the exploitation of Pistacia lentiscus, especially its fruit. The latter grows abundantly in the coastal forest scrubland, and a new effort is being made to boost the extraction of its oil by the inhabitants, due to the increase in the price per liter. Its extraction and crushing, which have remained at the stage of domestic craftsmanship, give a limited production for family use and can only be marketed in small quantities. Lentisk fruit oil is traditionally appreciated for its therapeutic and cosmetic uses and may be eligible for export or for use in specialized laboratories, which is a potential source of important income for farmers, especially rural women.

There are two methods of lentisk oil extraction: the traditional artisanal method and the mechanical method, the most recent. The first method is the oldest and the most widespread, it uses the stone grinder or on foot to grind the fruits. The decanting and separation of 
the oil is done in vats. The oil is collected after manual filtration (Camps and Faber, 1953). For the mechanical method, some modifications were made to the manufacturing process. Most of the basic operations were mechanized, with the exception of harvesting and washing, which remained manual. However, this mechanical extraction process is more practiced by men in the Lentisk oil mills.

Several studies have been carried out on P. lentiscus, using its different parts, to demonstrate its impressive uses and application. In 1999, Lanfranchi et al., focused their study on the production of Lentisk oil in Sardinia. Alloune et al., (2012) carried their study on lentisk oil as a feedstock for biodiesel production. However, for phytochemical characterization of $P$. lentiscus extracted oil, Charef (2011) conducted the chemical composition and phytochemical and nutriational properties of oils extracted from the black and red fruits. Meanwhile, a study was carried out by Djerrou (2011) to explore the pharmacotoxicological effects of $P$. lentiscus vegetable oil. In parallel, Mezni et al., (2012) evaluated the influence of the extraction method on the antioxidant and antibacterial activities of mastic fruit oil. Nevertheless, analysis of the fatty acid and sterol content of $P$ lentiscus oil, during fruit ripening, was also studied by Trabelsi et al., (2012). Meanwhile, Dahmoune et al., (2014) investigated $P$. lentiscus leaves phenolic compounds and their extraction techniques. Moreover, Djerrou (2014) was conducted the anti-hypercholesterolemic activity of Lentisk vegetable oil. Concurrently, Maameri-Habibatni (2014) achieved a study which intended to provide a scientific basis for the use of $P$. lentiscus vegetable oil in traditional medicine. In 2015, Haouli et al., carried out a study on the physicochemical and biochemical composition of the oil extracted from the plant fruits.

Given to the importance of Pistacia lentiscus in the socioeconomic life of the rural populations of the seven regions considered, this running study aims to improve the knowledge of its medicinal properties and its interest, through the characterization of the physicochemical parameters of the oils extracted from the fruits and the evaluation of their antibacterial and antifungal activities.

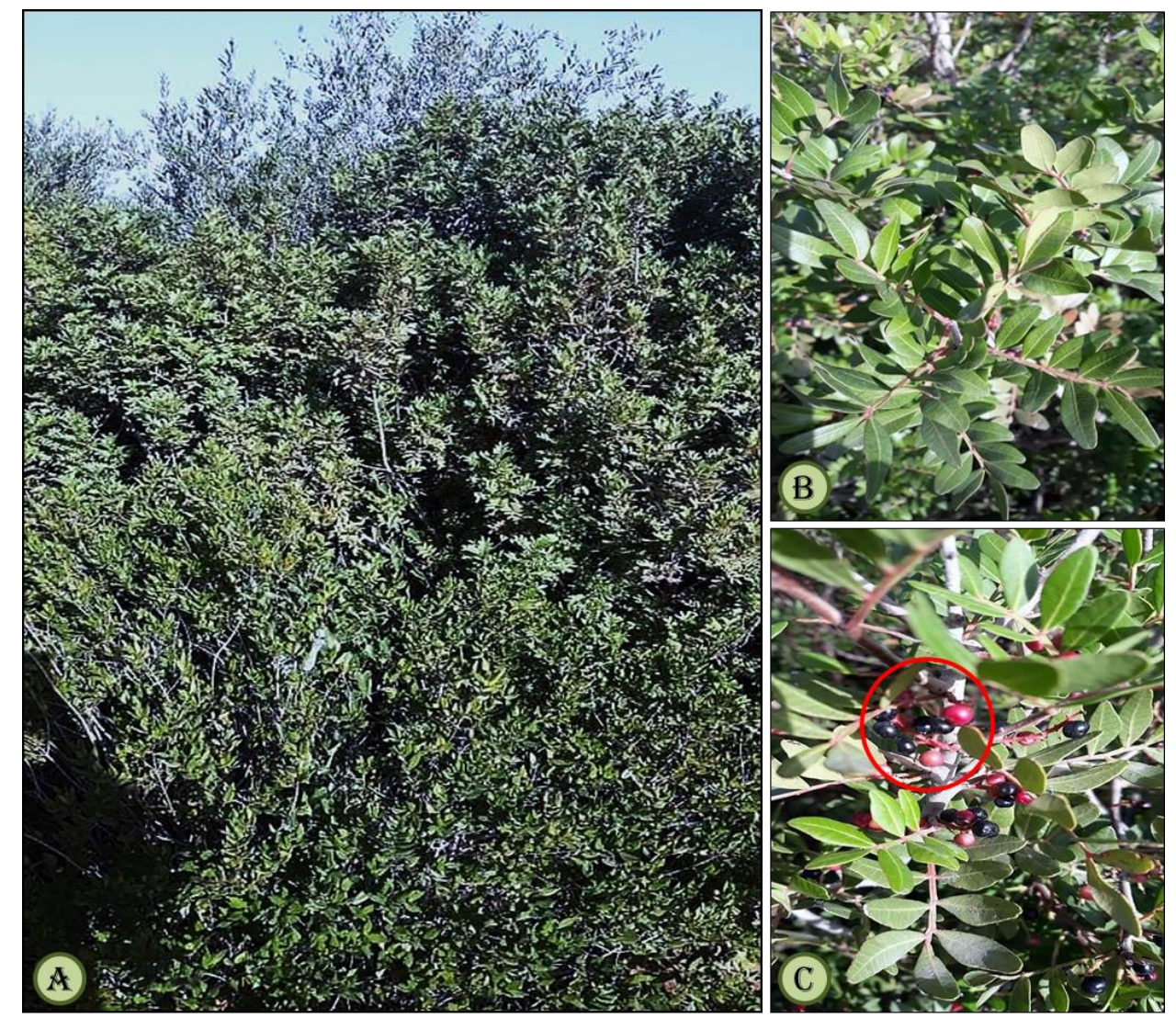

Photos (1): Pistacia lentiscus tree showing: A; woody shrub with evergreen leaves; B, pinnately compound leaves; $\mathrm{C}$, reddish-black fruits (red circle).

\section{MATERIALS AND METHODS}

\section{Source of the analyzed oil samples}

The study was conducted in seven regions of eastern Algeria: Annaba, Skikda, Ain Khiar, Bougous, Bouhadjar, Guelma and Souk Ahras (Figure 1). The choice of these areas was based on the abundance, socio-economic interest and use of Pistacia lentiscus in traditional medicine. Lentisk oil samples were collected from local populations, from fully ripe fruits, after then oil was extracted according to the ancestral method. These samples were immediately placed in 
hermetically sealed glass vials and wrapped in aluminum foil, and kept for laboratory analysis.

\section{Lentisk oil physicochemical characteristics}

The following physicochemical parameters were used to determine the quality of the oil samples considered. These parameters include: colour, humidity, acidity (free fatty acids formation because of rancidity), peroxide index (formation of primary oxidation products), phosphatide, saponification index and mucilage. They were determined in three replicates. The analyses were carried out at the "Society of fatty material" (Société des Corps Gras) Labelle Annaba, Spa (Algeria). These parameters were determined according to the methods mentioned below.

\section{Color}

The color of the collected Lentisk oil samples was determined using a colorimeter (Lovibond). Lovibond consists of three series of colored glasses: yellow, red and blue. Each series of glasses is additive, i.e. the absorbance of a given numbered glass is equivalent to the sum of the absorbance of two or more glasses, the sum of which is equal to that of the glass concerned. Color is an important factor in assessing the quality of oils. It reveals the nature of the technological treatment carried out on this oil. The color is indicated by mentioning the number of yellow, red and blue units, as follows:

$$
C=x j+y r+p b
$$

Where $\mathrm{C}$ : is the color of the oil; $\mathrm{j}$ : yellow pigment color, corresponding to chlorophyll; r: color pigment red, corresponding to carotenoid; b: blue color glass filter.

\section{Humidity}

It is the amount of water contained in a sample that is lost through heating. The humidity content is calculated from the difference in weight of a test sample before and after drying in an oven at $103^{\circ} \mathrm{C} \pm$ $2^{\circ}$ for $2 \pm 3$ hours, as follows:

$$
H \%=(m 1-m 2) 100 / P
$$

Where $P$, is the weight of the test sample; $m l$, is the oil mass in grams before drying; $m 2$, is the oil mass in grams after desiccation.

\section{Acidity index (AI \%)}

Acidity is the amount of free fatty acid resulting from the hydrolytic reactions of triglycerides. It is a quality criterion to report the state of conservation of oil (Kandji, 2001). It also allows controlling the level of hydrolytic, enzymatic or chemical degradation of triglyceride fatty acid chains (Abaza et al., 2002).

The principle is based on a mixture of $10 \mathrm{~mL}$ of oil sample and $100 \mathrm{~mL}$ of ethyl-alcohol was heated until the content started boiling. The hot content was cooled and titrated with $15 \% \mathrm{KOH}$ solution using phenolphthalein as endpoint indicator. The acid value is calculated as follows:

$$
\text { Acidity index }(\%)=\frac{M \cdot W t X V X N}{\operatorname{Pr}}
$$

Where $V$, is the number of milliliters of titrated solution of ethanolic $\mathrm{KOH}$; $N$, is the exact normality of the standard solution of ethanolic $\mathrm{KOH} ; M . w t$, is the molecular weight of $\mathrm{KOH}(56.1 \mathrm{~g} / \mathrm{mol})$ by whith molar mass $282 \mathrm{~g} / \mathrm{ml}$ of oleic acid (specific to lentisk oil) (lentisk oil) and $P r$, is the test sample in grams.

\section{The peroxide index $(P I)$}

It reflects the amount of peroxide present in the sample which is expressed in milliequivalents of active oxygen contained in one kilogram of product, oxidizing potassium iodide with iodine release. The PI index allows assessing the freshness of the oil, as follows:

$$
\text { Peroxide index }(P I)=\left(V-V_{0}\right) \times N \times 100 / M
$$

Where $V$, is the volume of $\mathrm{Na}$ thiosulfate in the sample; $V 0$, is the volume required to titrate the white; $N$, is the exact title of $\mathrm{Na}$ thiosulfate used and $M$, oil sample in grams.

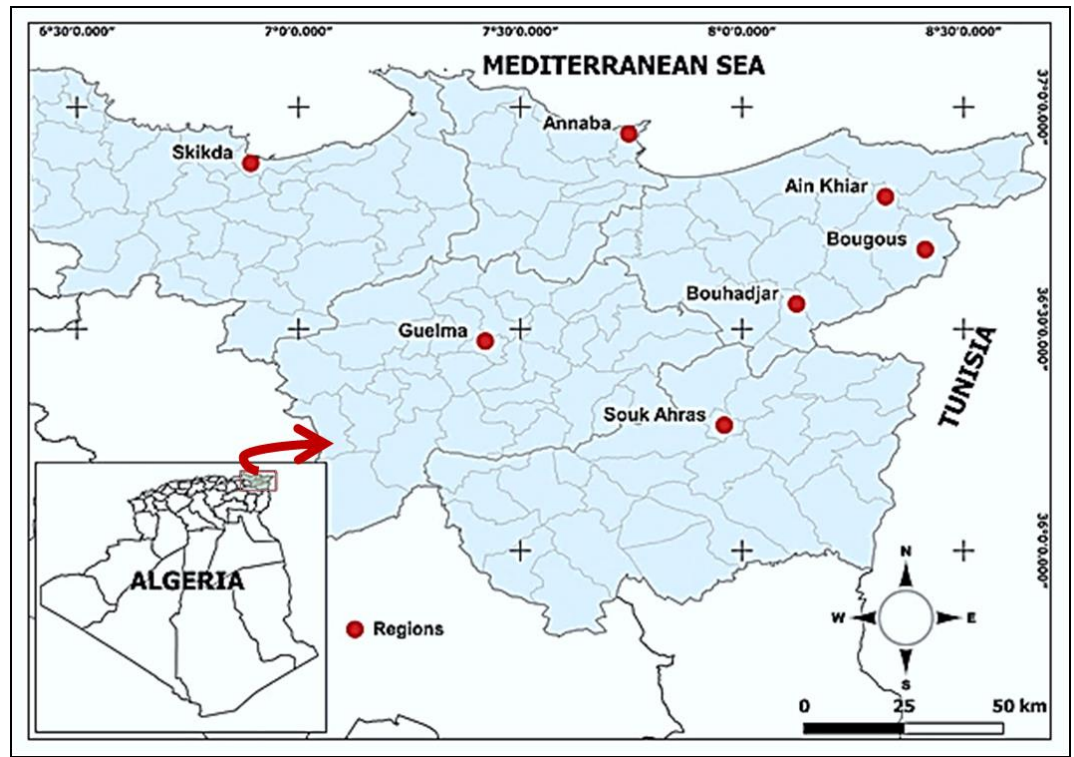

Figure (1): Location of provenance regions from where Lentisk oil samples were collected. 


\section{Phosphatides}

Determination of phosphatides can be done by insolubilizing the phosphatides in a solvent of the oil that does not dissolve it like acetone, using the following equation:

$$
\% \text { Phosphatides }=\frac{(P 1-P 2) X 100}{P}
$$

Where $P 1$ and $P 2$, are the filter weight before and after filtration; $P$, is the weight of the oil sample.

The saponification index (SI)

The saponification index is the number of milligrams of $\mathrm{KOH}$ required to neutralize the free acidity and to saponify the esters of $1 \mathrm{~g}$ of lipid. The value of the saponification index allows to estimate the lengths of the carbon chains of the fatty acids constituting the oil, and to calculate the average molecular weights of the fatty acids and triglycerides contained in the oil. The following equation was used for calculation:

$$
S I=\frac{(V 0-V 1) X 56.1 X N}{P}
$$

Where $S I$, is the Saponification index; $V O$ and $V I$, are the volume of $\mathrm{HCl}$ solution used for the blank and oil sample, respectively; $N$, is Normality of the $\mathrm{HCl}$ solution and $P$, oil sample.

\section{Determination of mucilage}

A quantity of crude oil is poured into a beaker in a sand bath. When the temperature of the oil increases, a few drops of hydrochloric acid are added. The formation of a green ring is a sign of the existence of mucilage traces. The green coloring of all the oil will be a sign of the existence of a large quantity of mucilage.

\section{Study of the antibacterial and antifungal properties}

This part of the study was carried out in "Marzouk Ibrahim Polyclinic laboratory" at El-Tarf city. To evaluate the antibacterial activity of Pistacia lentiscus oil samples, Muller Hinton (MH) agar and B.G.T nutrient were used. Bacterial pathogens tested were propagated on nutrient broth to obtain a fresh culture. The bacterial strains tested were Pseudomonas aeruginosa, Klebsiella pneumonia (Gram-negative bacteria); and Staphylococcus aureus (Gram-positive bacteria).

The well technique was performed in which each well, $100 \mu \mathrm{l}$ of oil samples (HV) were added on a bacterial seeded agar plate. After 24-hour incubation at $37^{\circ} \mathrm{C}$, a reading was taken to detect the activity and determine the minimum inhibitory concentrations (MIC). Different concentration of plant extracts was prepared in test tubes by the two-in-two dilution method $(1 / 2,1 / 4,1 / 8,1 / 16,1 / 32)$ from a stock solution with an initial concentration of $500 \mathrm{mg} / \mathrm{ml}$ (Ossou et al., 2004). The activity of the samples was represented by a clear halo zone formed around each well. The results were expressed in four levels of activity following the method of Ponce et al., (2003), in which (-) no activity; diameter of inhibition zone less than
$8 \mathrm{~mm}$ (ID $<8 \mathrm{~mm}$ ) will consider $(+)$; 9-14mm inhibition diameter will be given $(++)$; strong activity of the samples will represent by $(+++)$, ID is ranged between $15-19 \mathrm{~mm}(15 \mathrm{~mm} \leq \mathrm{D} \leq 19 \mathrm{~mm})$, and very strong activity represents by $(++++)$ in which ID is more than $20 \mathrm{~mm}$ ( $\mathrm{D}>20 \mathrm{~mm})$.

For antifungal activity, work was performed in the Laboratory of Plant Biology at Chadli Benjedid University (El Tarf). Three fungal strains were tested: Verticillium sp, Pythium sp and Phytophthora $s p$. These fungal cultures are belong to group Oomycetes which are known for their pathogenic effect on plants as fruit trees, ornamental trees, vegetables, etc. PDA (Potato-Dextrose Agar) was used to carry the activity test.

\section{Statistical analysis}

The results were analyzed using statistical software $\mathrm{R}$ version 4.0.1 (2020). The data are represented in means \pm standard deviation and $p<0.05$ was considered as significance level. The analysis of variance (ANOVA One-way) and Tukey-test were performed to determine whether there was a difference or not in physicochemical parameters among Lentisk oil samples collected from different regions. Principal Component Analysis (PCA), using a matrix (Regions / oils physicochemical parameters) was also performed to evaluate and the rank Lentisk oil physicochemical variation among the studied regions.

\section{RESULTS}

\section{Lentisk oil physicochemical characteristics}

The average values of physicochemical parameters obtained from this study have shown highly differences between the seven regions from which our oil samples were collected (One-Way ANOVA, $p<0.001$; Table 1). The yellow color parameter values at the different regions presented quite high values than red one. Furthermore, yellow color average values were higher than the International Olive Council (IOC) standards for the seven regions considered (Table 1). However, the red color average values were only above the IOC at five regions (Souk Ahras, Annaba, Ain Khiar, Bouhadjar and Bougous) (Table 1).

Humidity levels recorded for the different lentisk oil samples showed a variation in values from one locality to another but for the most part remain within the standards $(\leq 1 \%)$. The percentages values were varied from $0.17 \%$ (Souk Ahras) to $0.99 \%$ (Guelma). Significant differences were recorded between humidity levels for the majority of oils tested (One-way Anova, $p$ <0.000) (Table 1), except between: Guelma and Annaba (Tukey-test, $p=0.99$ ), Skikda and Souk Ahras (Tukey-test, $p=0.71$ ), Skikda and Ain Khiar (Tukeytest, $p=0.76$ ) and Souk Ahras and Bouhadjar (Tukeytest, $p=0.09$ ).

Acidity index of lentisk oils studied was above the standards for all localities except Skikda and Ain Khiar. The maximum value recorded was that of Bouhadjar $(8.36 \%)$. High significant differences of 
acidity levels were recorded between the majorities of oils tested (One-way Anova, $p<0.000$ ) (Table 1). However, no significant difference was found between Bougous and Guelma oil samples (Tukey-test, $p=0.99$ ), Bouhadjar and Bougous (Tukey-test, $p=0.69$ ) and those of Bouhadjar and Guelma (Tukey-test, $p=0.91$ ). The peroxide values recorded in this study were for the most part in compliance with standards. The highest significant value were those of Guelma oils (6.23 $\mathrm{meq} / \mathrm{kg}$ ), followed by oil samples collected from Skikda and Souk Ahras (4.18 meq/kg and $4.04 \mathrm{meq} / \mathrm{kg}$, respectively). Meanwhile, the lowest value recorded was that of Bougous locality oil $(0.54 \mathrm{meq} / \mathrm{kg})$. Highly significant differences were verified among peroxide indices values of almost all lentisk oils tested (Oneway Anova, $p<0.000$ ) (Table 1). However, no significant differences were reported between: Skikda and Souk Ahras regions (Tukey-test, $p=0.96$ ) and Ain Khiar and Skikda (Tukey-test, $p=0.74$ ).

Saponification indices and phosphatide values showed values that remain within the international standards (IOC). The lowest saponification indices values were those of Bougous and Skikda, while, the highest but still within standards were those of Annaba and Guelma. For phosphatide values, the highest were recorded in oil samples collected from of Áin Khiar, followed by those of Guelma and Annaba. The analysis of variance showed high significant differences among oil samples collected from most regions (One-way Anova, $p<0.000$ ) (Table 1). In addition, the mucilage test confirmed the purity of each oil sample.

\section{Statistical interpretation of results}

The Principal Component Analysis (PCA) revealed that the two first dimensions, representing $59 \%$ of the total variance, highlighted the difference among physicochemical parameters of region-oil samples considered in this study. The first dimension (38.5\% of the total variance) separated regions with high AI (Bou-hadjar and Bougous) from the other regions (Figure 2). This is probably due to alteration of the oil composition during the extraction process, as an excess of water can combine with oil under local temperature which may lead to hydrolysis of triglycerides and an increase in acidity value (Figure 3; Table 1). The second axis (20.5\% of the total variance) contrasted the regions with a highest values of physicochemical parameters indices (Peroxide index $(\mathrm{PI})$, humidity $(\mathrm{H})$, phosphatides (P) and saponification indices (SI) to lowest ones (Figures 2 and 3; Table 1).

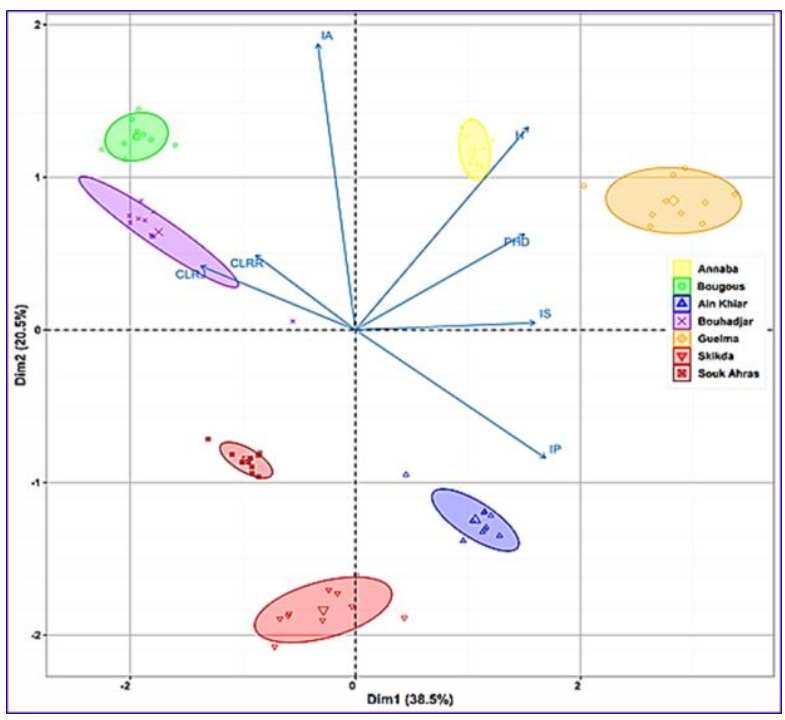

Figure (2): Principal correspondence analysis scatter plot with the first two components displaying the distribution of physicochemical parameters considered in the study (ellipse $=95 \%$ confidence interval).

\section{Study of the antibacterial and antifungal properties Antibacterial activity}

The oil samples tested showed no inhibitory effect on the three strains of bacteria tested. No inhibition zones were observed around the wells. Therefore, these samples have no antibacterial activity (S1).

\section{Antifungal activity}

Data obtained showed that Lentisk oil samples studied have an anti-fungal activity on fungal strains tested, where their activity was varied depending on the oil concentration (Table 2; S2).

Table (1): Physicochemical characteristics of the Lentisk oil samples. The values represented are means \pm standard deviation.

\begin{tabular}{|c|c|c|c|c|c|c|c|c|}
\hline \multirow{3}{*}{$\begin{array}{l}\text { Sampling } \\
\text { regions }\end{array}$} & \multicolumn{8}{|c|}{ Measured Parameters } \\
\hline & \multicolumn{2}{|c|}{ Color } & \multirow{2}{*}{$\underset{(\%)}{\text { Humidity }}$} & \multirow{2}{*}{$\begin{array}{l}\text { Mucila } \\
\text { ge }\end{array}$} & \multirow{2}{*}{$\begin{array}{l}\text { Acidity } \\
\text { index }\end{array}$} & \multirow{2}{*}{$\begin{array}{c}\text { Peroxide } \\
\text { index } \\
\left(\text { meq }_{2} / \mathrm{Kg}\right)\end{array}$} & \multirow{2}{*}{$\begin{array}{c}\text { Saponificatio } \\
\mathbf{n} \text { index } \\
(\mathrm{mg})\end{array}$} & \multirow{2}{*}{$\begin{array}{c}\text { Phosphatides } \\
(\%)\end{array}$} \\
\hline & Yellow & Red & & & & & & \\
\hline Guelma & $22.30 \pm 0.95$ & $3.98 \pm 0.92$ & $0.99 \pm 0.05$ & Brown & $8.25 \pm 0.21$ & $6.23 \pm 0.11$ & $192.15 \pm 22.24$ & $1.09 \pm 0.08$ \\
\hline Skikda & $28.28 \pm 1.36$ & $4.24 \pm 0.53$ & $0.21 \pm 0.06$ & Green & $3.19 \pm 0.14$ & $4.18 \pm 0.13$ & $136.44 \pm 24.94$ & $0.30 \pm 0.03$ \\
\hline Souk Ahras & $55.67 \pm 0.39$ & $9.49 \pm 0.35$ & $0.17 \pm 0.02$ & Brown & $4.52 \pm 0.16$ & $4.04 \pm 0.47$ & $182.44 \pm 0.19$ & $0.20 \pm 0.00$ \\
\hline Annaba & $38.30 \pm 1.49$ & $8.50 \pm 0.71$ & $0.98 \pm 0.05$ & Green & $5.72 \pm 0.26$ & $2.82 \pm 0.12$ & $193.4 \pm 5.42$ & $1.00 \pm 0.00$ \\
\hline Ain Khiar & $21.84 \pm 0.50$ & $8.08 \pm 0.56$ & $0.18 \pm 0.05$ & Green & $2.24 \pm 0.12$ & $3.95 \pm 0.73$ & $178.30 \pm 1.89$ & $1.31 \pm 0.03$ \\
\hline Bougous & $34.38 \pm 0.36$ & $10.16 \pm 0.63$ & $0.33 \pm 0.08$ & Brown & $8.22 \pm 0.22$ & $0.54 \pm 0.13$ & $117.76 \pm 0.35$ & $0.69 \pm 0.00$ \\
\hline Bouhadjar & $41.15 \pm 23.66$ & $8.01 \pm 1.89$ & $0.23 \pm 0.09$ & Brown & $8.36 \pm 0.27$ & $2.27 \pm 0.07$ & $144.52 \pm 0.38$ & $0.48 \pm 0.00$ \\
\hline IOC value ${ }^{\dagger}$ & $Y \leq 7$ & $\mathrm{R} \leq \mathbf{8}$ & $\leq 1 \%$ & - & $<3.3 \%$ & $\leq \mathbf{2 0}$ & $188-196 \mathrm{mg}$ & $184-196 \mathrm{mg}$ \\
\hline Sign. level & $<0.000 * * *$ & $<0.000 * * *$ & $<0.000 * * *$ & & $<0.000^{* * * *}$ & $<0.000 * * *$ & $<0.000 * * *$ & $<0.000 * * *$ \\
\hline
\end{tabular}

${ }^{\dagger}$ IOC, International Olive Council; Y: yellow color; R, red color; meq, milliequivalent; Kg, kilogram; mg: milligram 


\section{DISCUSSION}

Few studies have been carried out on the physicochemical quality and the antibacterial and antifungal power of medicinal plants oils. Most of researches conducted were devoted to ethnobotanical studies which have become increasingly important in recent decades, particularly in North Africa and Algeria (Fakchich and Elachouri, 2014; Boughrara and Legseir, 2016; Rhattas et al., 2016; Bouasla and Bouasla, 2017; Katiri et al., 2017; Miara et al., 2018; Lazli et al., 2019; Senouci et al., 2019; Zahir et al., 2020).

To evaluate Lentisk oils quality, the parameters selected in this study are considered as key of interest because they determine the shelf-life quality and hence the economic value of oils, which were confirmed by Decker et al., (2010) and Endo et al., (2018). Indeed, several authors have noted that rancidity of vegetable oils may pose health risks like cancer or inflammation because of the formation of toxic and reactive oxidation products (Mukherjee et al., 2009; Mehmood et al., 2012; Negash et al., 2019).

The "color parameter" was considered, in this study, to estimate the quality of oils where it has been proven that food pigments have beneficial effects on human health as antioxidant (Olson, 1999; Beutner et al., 2001; Moyano et al., 2010). Data obtained in the present study showed that oils color values were related to high levels of natural pigments in oil

samples. This reported data are in agreement with data obtained, by Meléndez et al. (2003). These pigments are generally Chlorophyll and carotenoid pigments. They are important quality parameters because they correlate with color, which is a basic attribute of oil quality.

The importance of their content in the oil depends on various factors, including fruit maturity, climatic conditions, soil type and extraction methods (El Harfi et al., 2015). The results obtained indicate that the yellow color exhibited higher values than standards for the seven regions. On the other hand, the color red was above the standard values for five regions: Souk Ahras, Annaba, Ain Khiar, Bouhadjar and Bougous. In confirmation to our results Merzougui (2015) reported a value of 52 for the yellow color and 2 for the red color, in his study, on characterization of Lentisk oil in El Tarf, a locality in eastern Algeria not far from our study sites. The strong yellow coloring obtained in this study reflects very high levels of chlorophyll in all oil samples and particularly in Souk Ahras and Bougous regions, which also have high beta-carotene content, exceeding the standards. Several studies indicated that chlorophyll pigments are considered as antioxidants which have beneficial effect on human health (LanferMarquez et al., 2005; Moyano et al., 2010) and may also be beneficial in the prevention of cancer (Ferruzzi and Blakeslee, 2007).

Some carotenoid are precursors of vitamin A and
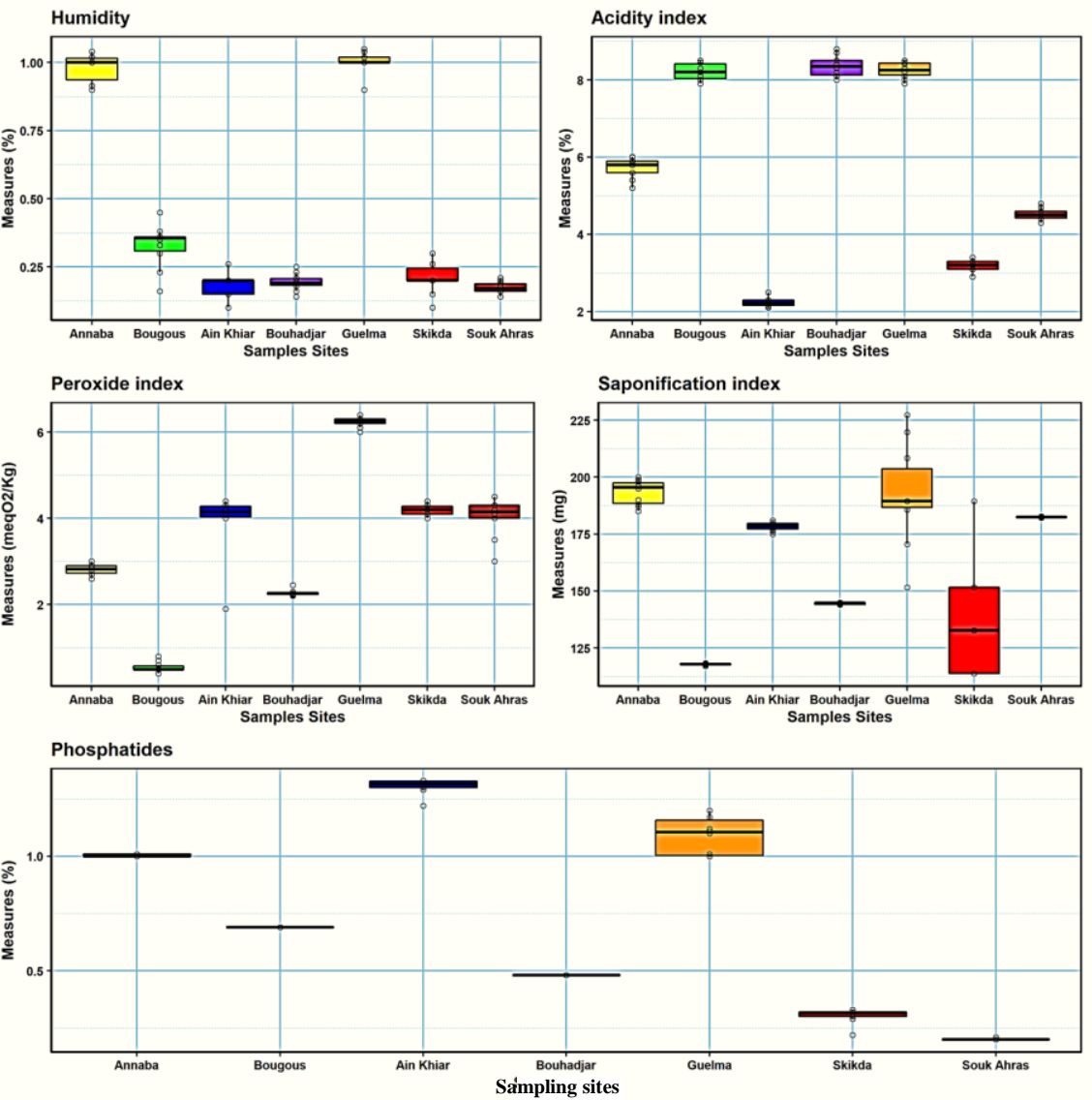

Figure (3): Variations in physicochemical parameters of oil samples collected from different study regions 
Table (2): Antifungal activity of Lentisk oil samples, collected from different Algerian provenance regions and detection of the minimal inhibitory concentration on fungal pathogen tested.

\begin{tabular}{|c|c|c|c|c|}
\hline \multirow{3}{*}{ Fungal strains } & \multicolumn{4}{|c|}{ Guelma oil } \\
\hline & \multicolumn{4}{|c|}{ Dilution used } \\
\hline & $\mathbf{T}^{\dagger}$ & $1 / 2$ & $1 / 4$ & $1 / 8$ \\
\hline Phytophthora sp. & + & + & + & - \\
\hline Verticillium $s p$. & + & + & + & $+/-$ \\
\hline \multirow[t]{2}{*}{ Pythium sp. } & + & + & + & - \\
\hline & \multicolumn{4}{|c|}{ Skikda oil } \\
\hline Phytophthora sp. & + & + & $+/-$ & + \\
\hline Verticillium sp. & + & + & + & $+/-$ \\
\hline \multirow[t]{2}{*}{ Pythium sp. } & + & + & + & + \\
\hline & \multicolumn{4}{|c|}{ Souk Ahras oil } \\
\hline Phytophthora sp. & + & + & $+/-$ & - \\
\hline Verticillium sp. & + & + & + & $+/-$ \\
\hline \multirow[t]{2}{*}{ Pythium sp. } & + & + & $+/-$ & - \\
\hline & \multicolumn{4}{|c|}{ Annaba oil } \\
\hline Phytophthora sp. & + & + & + & + \\
\hline Verticillium sp. & + & + & + & + \\
\hline \multirow[t]{2}{*}{ Pythium sp. } & + & + & + & + \\
\hline & \multicolumn{4}{|c|}{ Ain Khiar oil } \\
\hline Phytophthora sp. & + & + & + & + \\
\hline Verticillium sp. & + & + & + & + \\
\hline \multirow[t]{2}{*}{ Pythium sp. } & + & + & + & + \\
\hline & \multicolumn{4}{|c|}{ Bougous oil } \\
\hline Phytophthora sp. & + & + & + & $+/-$ \\
\hline Verticillium $s p$. & + & + & + & $+/-$ \\
\hline \multirow[t]{2}{*}{ Pythium sp. } & + & + & $+/-$ & - \\
\hline & \multicolumn{4}{|c|}{ Bouhadjar oil } \\
\hline Phytophthora sp. & + & + & $+/-$ & - \\
\hline Verticillium $s p$. & + & + & $+/-$ & - \\
\hline Pythium sp. & + & + & - & - \\
\hline
\end{tabular}

${ }^{\dagger} \mathrm{T}, 100 \mu \mathrm{l}$ of oil used; (+), presence of inhibitory effect; (-), no antifungal activity.

effective antioxidants, they also prevent of serious human ailments like skin or cardiovascular diseases and as well cancer (Bernstein, 2002; Palozza, 2004; Voutilainen et al., 2006; Wang et al., 2008). They are natural chemical substances involved in the oxidation mechanisms of oil; their presence in sufficient quantities in the oil delays the photo-oxidation phenomenon and preserves the oil quality during storage (Lazzer et al., 2006).

During this study, humidity levels recorded showed a variation in values from one locality to another but for the most part they remain within the standards. Several authors have reported various values compared with ours for the same regions. Bensalem (2015) reported a humidity of $0.64 \%$ for Skikda and $0.50 \%$ for Guelma. Merzougui (2015) reported that the humidity rate of $0.84 \%$ for El Tarf, which is higher than those obtained for Ain Khiar, Bougous and Bouhadjar, the three regions situated no far. This variation would be due to the artisanal extraction process, in which the use of water differs from one individual to another and probably from one region to another. To reduce humidity levels retained inside the fruits, these oils might require additional heating before extraction (Okechalu et al., 2011; Negash et al., 2019).

The oil humidity percentage is also a good indicator for hydrolysis of triglycerides (substance may pose a risk to human health). Indeed, high humidity percentage leads to the release of free fatty acids ten times more sensitive to oxidation than when they are in bound form. Higher humidity content, greater is the risk. Thus, it appears in our case that Guelma and Annaba oils are the most likely to present a risk of hydrolytic alteration and indicated that they are likely to undergo rancidity, which can drastically reduce their value by breaking down essential fatty acids (De Souza 
et al., 2015; Negash et al., 2019).

The acidity index of Lentisk oils studied was higher than the standards for all localities except Skikda and Ain Khiar. Acidity controls the level of hydrolytic, enzymatic or chemical degradation of triglyceride fatty acid chains (Abaza et al., 2002). Karleskind and Wolff (1992) indicated that a fat is protected against hydrolytic degradation if its acidity is $\leq 0.1 \%$. The samples of Bouhadjar oil show the higher acidity value which is close to those noted by Maameri-Habibatni (2014) and Djerrou (2014), 8.5\% and 7\%, respectively for Lentisk oil from northeastern localities of Skikda and El Milia. The acidity index recorded for Skikda region in this study, $3.19 \%$, is slightly higher than that reported by Boukeloua et al., (2012), 2.27\%, and Bensalem (2015) for Lentisk oil from Azzaba, located not far from Skikda. The latter values are practically similar to those obtained in this work for Ain Khiar locality, $2.24 \%$. It can therefore be concluded that all the samples in this study may have been exposed to possible alterations. Demnati et al., (2011) indicated that high acidity can be produced by the combined action of temperature and additional water during the artisanal mining process. Hilali et al., (2005) reported that excess water catalyzed the hydrolysis of triglycerides and thus led to increased acidity. Another criterion to be considered is that the oils tested did not undergo any refining treatment in which soda neutralization is applied to them.

Most of the peroxide values recorded in this study are in compliance with standards. Other studies conducted with oils from the same regions indicate values more or less different. Merzougui (2015) and Bensalem (2015) reported values higher than those of this study, $5.39 \mathrm{meq} / \mathrm{kg}$ in El Tarf and $11.91 \mathrm{meq} / \mathrm{kg}$ in Skikda. However, for Guelma region, Bensalem (2015) obtained lower values than our study $(4.17 \mathrm{meq} / \mathrm{kg})$. The values obtained being less than 10 meq $\mathrm{O}_{2} / \mathrm{kg}$ of oil, therefore, they comply with the standards of most conventional oils (FAO, 1981; ISO3960, 2007). Therefore, the oil samples studied can be considered to have an acceptable level of oxidation, as indicated by Rossell (1993). It demonstrates good hygienic and manufacturing practices for the oils sampled. Indeed, oxidation of oil begins after the fruit has been harvested from the tree, and continues during storage and processing. Fats can oxidize in the presence of oxygen and other factors like high temperature, water, enzyme, etc. (Chekroun, 2013). Good storage conditions and appropriate extraction methods used by artisans can help assess the early stages of oxidative deterioration of the product (Tchiegang et al., 2004; Marmesat et al., 2009). A high peroxide value could be induced by the presence of certain substances such as carotenoids, vitamins $\mathrm{A}$ and $\mathrm{E}$, which can undergo similar oxidation reactions with peroxide formation (Kandji, 2001).

Saponification values calculated in this study showed values that remain within the standards. However, they were lower than those found in other researches, especially for the regions of Guelma and
Skikda where Bensalem (2015) recorded an average value of $216.89 \mathrm{mg}$ and $211.95 \mathrm{mg}$, respectively. Merzougui (2015) reported an average saponification index of $191.45 \mathrm{mg}$ for El Tarf region, which is higher than the values obtained for oil samples of Ain Khiar, Bougous and Bouhadjar which are located no far.

Phosphatide values recorded, during this study, are for the most part in compliance with standards. The mucilage test confirmed the purity of the samples of tested oil. Thus, the green colored mucilages attest to be more or less pure oil, extracted under good conditions and free of impurities. This is the case of samples from Skikda, Annaba and Ain Khiar regions. The dark-colored mucilages (brown) probably indicate that during the extraction process the fruits were mixed with leaves, twigs or stems.

Highest values of humidity, phosphatides and saponification indices were depend on the pressing conditions and the quality of the oil: virgin (crude) or refined. The high saponification index reflects the low molecular weight of the fatty acids, which can be explained by the high moisture content that causes hydrolytic alteration of the oils. Therefore, differences in the values of the physicochemical parameters recorded for considered regions could be attributed to the variation in environmental factors and climate. Indeed, altitude is also factor modifying plant phytochemistry parameters and should be considered (Ibanez and Usubillaga, $2006 \mathrm{a} \& \mathrm{~b}$; Tkachev et al., 2006; Haider et al., 2009).

The study of antibacterial and antifungal properties of Lentisk oils showed that antibacterial activity of the tested oil to specific bacterial pathogens used not effective (S1). These results may be related to bacterial strains used where they considered as resistant pathogens (Tassou and Nychas, 1995; Bonsignore et al., 1998; Benhammou and Bekkara, 2009). However, these oils exhibited an inhibitory effect against fungal strains tested where no fungal growth was recorded (S2). The fact that some bacterial strains are resistant to certain oils can be attributed to the data obtained. This prediction is consistent with those reported by Cosentino and Tuberoso (1999), De Billerbeck (2002) and Bammou et al., (2015) who shown that extracts from other parts of Pistacia lentiscus (leaves, stem, mastic or gum) have antimicrobial effects on different types of strains. Indeed, a study reported by Tahiri (2008) showed that Lentisk leaves have a remarkable antimicrobial effect on Salmonella enteritidis with inhibition zones of $8.6 \pm 0.9 ; 16.5 \pm 1.3 ; 14.6 \pm 0.2$ and $13.8 \pm 0.4$ respectively at $5 \mu \mathrm{g} / \mathrm{ml}$ ). In parallel, some literatures had reported that antibacterial activity of Pistacia lentiscus oil may be attributed to the chemical composition of the plant, including its richness in total polyphenols, flavonoids and tannins. Tannins have been shown to be bactericidal against several strains as: Staphylococcus aureus (Fogliani et al., 2005), Bacillus cereus, Escherichia coli, Salmonella antum, Clostridium perfringins, Klebsiella pneumoniae (Taguri et al., 2006), Vibrio parahaemolyticus (Nagayama et al., 2002), Streptococcus bovis (Jones et 
al., 1994). Various studies have reported the high antioxidant capacity of the plant species (Longo et al., 2007; Arab et al., 2014; Dahmoune et al., 2014; Djedaia 2017). Senouci et al., (2019) reported that aerial parts contain terpineol, which is known to be effective against microbial activity. From the literature reviewed, it appears that Pistacia lentiscus leaves have a higher yield of phenolic compounds than fruits or essential oils (Arab et al., 2014; Bampouli et al., 2015).

In view of these mentions, it seems obvious that lentisk oil extracted from fruits does not have convincing effects with regard to bacterial strains compared to leaf extracts which are much richer in phenolic compounds. Due to the lack of antibacterial activity data on Lentisk oil samples tested in this study, it can be assumed that these oils may have low polyphenolic content. However, this should be verified in future researches. Bara et al., (2007) reported the power of Pistacia lentiscus in inhibiting mycelial growth, which confirms the results of the antifungal activity obtained in this work with the fungal strains tested.

\section{CONCLUSION}

Although the results obtained in this study showed a variation in the physicochemical parameters among the several Pistacia lentiscus oils collected from different regions of north-eastern Algeria, their values remain within the standards attesting to a fairly good quality. However, the variations between these different physicochemical parameters can be explained by: (i) an alteration of oils during the extraction process, (ii) inappropriate storage conditions, (iii) variation in the environmental conditions of studied regions. The oils tested showed no antibacterial activity for the bacterial pathogen used but had an inhibitory effect on the fungal strains used.

These results are still preliminary and it would be interesting to conduct further studies to understand the molecular and cellular mechanisms of these effects. In addition, a phytochemical study should be carried out to determine the richness of the oil samples tested in phenolic compounds to better evaluate their antioxidant and antibacterial activities. Furthermore, the antifungal performances highlighted should be studied in more detail to consider the prospects for the application of these active ingredients as biological control agents capable of reducing the growth of fungi and moulds on field crops. Future work could also be envisaged to determine other biological activities of Pistacia lentiscus (anti-inflammatory, hypoglycaemic, antioxidant activities).

\section{AKNOWLEDGEMENTS}

The authors would like to acknowledge all the persons who contributed to this study, especially the students Raounek, Fakhreddine, Zoulikha, Habiba and Leila. This study was carried out as part of the doctoral thesis of Mr Beldi Moncef. We also express our grati- tude to the laboratories that helped us to carry out our analyses.

\section{REFERENCES}

ABAZA, L., M. MONGI, D. DOUJA AND M. ZARROUK 2002. Caractérisation des huiles de sept variétés d'olivier tunisiennes. Oléagineux, Corps Gras, Lipides, 9 (2): 174-179.

ALLOUNE, R., A. LIAZID AND M. TAZEROUT 2012. Etudes comparatives de deux plantes oléagineuses locales pour la production du biodiesel en Algérie. Revue des Energies Renouvelables, SIENR'12 Ghardaïa, 19 - 22.

AMARA, N., A. BENRIMA, C. ANBA AND H. BELKHIR 2019. Activité antimicrobienne de l'huile essentielle des fruits du Pistachier lentisque (Pistacia lentiscus L.). Revue Agrobiologia, 9 (2) : 1669-1676.

ARAB, K., O. BOUCHNAK AND K. YAHIAOUI 2014. Etude phytochimique et évolution de l'activitéle antimicrobienne et antioxydant de l'huile essentielle et des composés phénolique du Pistachier lentisque (Pitacia lentiscus L). Journal of Fundamental and applied Science, 6 (1) : 79-93.

BABA AISSA, F. 1999. Encyclopédie des plantes utiles. (Flore d'Algérie et du Maghreb). Substances Végétales d'Afrique, d'orient et d'occcident .Ed. Edas, Alger.368p.

BAMMOU, M., A. DAOUDI, I. SLIMANI, M. NAJEM, E. BOUIAMRINE, J. IBIJBIJEN AND L. NASSIRI 2015. Valorisation du lentisque «Pistacia lentiscus L. »: Etude ethnobotanique, screening phytochimique et pouvoir antibactérien. Journal of applied biosciences. 86: 7966 - 7975.

BAMPOULI, A., KYRIAKOPOULOU, K., PAPAEFSTATHIOU, G., LOULI, V., ALIGIANNIS, N., MAGOULAS, K. AND MAGDALINI, K. (2015). Evaluation of total antioxidant potential of Pistacia lentiscus var. chia leaves extracts using UHPLC-HRMS. J of Food Engineering.

BARA, A., V. CORONEO, S. DESSI, P. CABRAS AND A. ANGIONI. 2007. Characterization of the volatile constituents in the essential oil of Pistacia lentiscus L. from different origins and its antifungal and antioxidant activity. Journal of Agricultural and Food Chemistry, 55 (17) : 7093-8.

BELLAKHDAR, J. 1997. La Pharmacopee Marocaine Traditionnelle : Medecine Arabe Et Savoirs Populaires. Editions Le Fennec, (Ed.) (Eds.), Ibis Press, Casablanca, Morocco : 764p.

BENHAMMOU, N. AND F. BEKKARA 2009. Activité antibactérienne de l'huile essentielle de Pistacia lentiscus L. de deux stations de la région de Tlemcen (Algérie). Actes du congrès international des 22-24 mars 2007, Mezraoua (Taounate) \& Fès, Maroc, 281-285.

BENSALEM, G. 2015. L'huile de Lentisque Pistacia lentiscus dans l'Est algérien: caractéristiques 
physic-chimique et composition en acides gras. Thèse de magister. Univ. Constantine I. 117p.

BENSEGUENI, A. 2007. Les onguents traditionnels dans le traitement des plaies et des brulures. Thèse d'Etat en sciences vétérinaires. Université Mebtouri. Constantine. p.21-22.

BERNSTEIN, P. S. 2002. New insights into the role of the macular carotenoids in age-related macular degeneration. Resonance Raman studies. Pure and Applied Chemistry $74:$ 1419-25.

BEUTNER, S., B. BLOEDORN AND S. FRIXEL. 2001. Quantitative assessment of antioxidant properties of natural colorants and photochemical: Carotenoids, flavonoids, phenols and indigoids. The role of b-carotene in antioxidant functions, Journal of the Science of Food and Agriculture, 81, pp.559568.

BILLERBECK, G. 2002. Les contaminations biologiques des biens culturels : Essai d'utilisation d'huile essentielle en traitement de l'aire. Ed : Elsevier.357-365.

BONSIGNORE, L., F. COTTIGLIA AND G. LOY 1998. Antibacterial activity of Pistacia lentiscus aerial parts. Fitoterapia LXIX(6): 537-538.

BOUASLA, A. AND I. BOUASLA. 2017. Ethnobotanical survey of medicinal plants in northeastern of Algeria. Phytomedicine. 36:68-81.

BOUGHRARA, B. AND B. LEGSEIR. 2016. Ethnobotanical study close to the population of the extreme north east of Algeria: The municipalities of El Kala National Park (EKNP). Industrial Crops and Products; 88:2-7.

BOUKELOUA, A., A. BELKHIRIB, Z. DJERROUA, L. BAHRIC, N. BOULEBDAD. AND Y. HAMDI PACHAA. 2012. Acute toxicity ofOpuntia ficus indicaandPistacia lentiscusseed oils mice. African Journal of Traditional, Complementary and Alternative medicines, 9(4) : 607-611.

CAMPS, G. AND H. FABER. 1953. « L'olivier et huile dans l'agri que romaine » $\mathrm{Ed}$ : imprimerie officielle, Alger.

CHAREF, M. 2011. Contribution à l'étude de la composition chimique et étude des propriétés phytochimiques et nutritionnelles des lipides des fruits de Pistacia lentiscus et du Quercus. Thèse de doctorat. $84 \mathrm{p}$

CHEKROUN, N. 2013. Détermination de la capacité antioxydante des huilesvégétales : Huile Afia. Mémoire de fin d'étude. Université Abou Bekr Belkaid. Tlemcen. 72p.

COSENTINO, S. AND C. I. G. TIBEROSO. 1999. Invitro antimicrobial activity and chemical composition of sardinian Thymus essential oils. Letters in Applied Microbiology, 29 (2) : 130-135.

DAHMOUNE, F., G. SPIGNO, K. MOUSSI, H. REMINI, A. CHERBAL AND K. MADANI. 2014. Pistacia lentiscus leaves as a source of phenolic compounds: Microwave-assisted extraction optimized and compared with ultrasound-assisted and conventional solvent extraction. Industrial Crops and Products. 61: 31-40.
DECKER, E. A., R. J. ELIAS, D. J. MCCLEMENTS. 2010. Oxidation in foods and beverages and antioxidant applications: management in different industry sectors. Amsterdam: Elsevier.

DEMNATI, D., S. SÁNCHEZ, R. PACHECO, M. ZAHAR AND L. MARTÍNEZ. 2011. Comparative study of argan and olive fruits and oils. Actes du Premier Congrès International de l'Arganier, 7 : 435-441.

DE SOUZA, R. J., A. MENTE, A. MAROLEANU, A. I. COZMA, V. HA, T. KISHIBE. 2015. Intake of saturated and trans unsaturated fatty acids and risk of all-cause mortality, cardiovascular disease, and type 2 diabetes: systematic review and metaanalysis of observational studies. British Medical Journal, 351:h3978.

DJEDAIA, S. 2017. Etude physico-chimique et caracterisation $\mathrm{du}$ fruit de la plante lentisque (Pistacia lentiscus L.) Thèse de doctorat en sciences. Université Badji Mokhtar - Annaba. Algérie. 138p

DJERROU, Z. 2011. Etude des effets pharmacotoxicologique de plante médicinales d'Algérie : l'activité cicatrisante et innocuité de l'huile végétale de Pistacia lentiscus L. Thèse de Doctorat en sciences. Université Mentouri, Faculté des sciences de la nature et de la vie, Constantine, 156 p.

DJERROU, Z. 2014. Anti-hypercholesterolemic effect of Pistacia lentiscus fatty oil in egg yolkfed rabbits: a comparative study with simvastatin. Chinese Journal of Natural Medicines, 12 (8): 0561-0566.

EL HARFI, M., A. NABLOUSSI, H. RIZKI, H. LATRACHE, S. ENNAHLI AND H. HANINE. 2015. Biochemical assessment of the genetic diversity among thirteen moroccan genotypes of sesame (Sesamum indicum). International Journal of Development Research, 5 : 4010-4020.

ENDO, Y. 2018. Analytical methods to evaluate the quality of edible fats and oils: the JOCS standard methods for analysis of fats, oils and related materials (2013) and advanced methods. Journal of Oleo Science, 67 (1): 1-10.

FAKCHICH, J, ELACHOURI M. 2014. Ethnobotanical survey of medicinal plants used by people in Oriental Morocco to manage various ailments. Journal of Ethnopharmacology. 154:7687. http://dx.doi.org/10.1016/j.jep.2014.03.016i

FERRUZZI, M. G., J. BLAKESLEE. 2007. Digestion, absorption, and cancer preventative activity of dietary chlorophyll derivatives. Nutrition Research, 27: $1-12$.

FOGLIANI, B., P. RAHARIVELOMANANA, J. P. BIANCHINI, S. BOURAIMA-MADJEBI AND E. HNAWIA. 2005. Bioactive ellagitannins from Cunonia macrophylla, an endemic cunoniaceae from New Caledonia. Phytochemistry, 66 : 241-247.

GARDELI, C., V. PAPAGEORGIOU, A. MALLOUCHOS, K. THEODOSIS AND M. KOMAITIS. 2008. Essential oil composition of Pistacia lentiscus L. and Myrtus communis L.: Evaluation of 
antioxidant capacity of methanolic extracts. Food Chemistry 107: 1120-1130

GONZÁLEZ-TEJERO, M. R., M. CASARESPORCEL, C. P. SÁNCHEZ-ROJAS, J. M. RAMIRO-GUTIÉRREZ, J. MOLERO-MESA, A. PIERONI, M. E. GIUSTI, E. CENSORII, C. DE PASQUALE, A. DELLA, D. PARASKEVAHADIJCHAMBI, A. HADJICHAMBIS, Z. HOUMANI, M. EL-DEMERDASH, M. ELZAYAT, M. HMAMOUCHI AND S. ELJOHRIG. 2008. Medicinal plants in the Mediterranean area: Synthesis of the results of the project Rubia. Journal of Ethnopharmacology 116: 341-357.

HAIDER, F., N. KUMAR, S. BANERJEE, A. A. NAQVI AND G. D. BAGCHI. 2009. Effect of Altitude on the essential Oil Constituents of Artemisia roxburghiana Besser var. purpurascens (Jacq.) Hook. Journal of Essential Oil Research, 21 : 303-304.

HAMEL T., S., SADOU, R. SERIDI, S. BOUKHDIR AND A. BOULEMTAFES. 2018. Pratique traditionnelle d'utilisation des plantes médicinales dans la population de la péninsule de l'Edough (Nord-est algérien). Ethnopharmacologia, 59: 7581

HAMLAT, N. AND A. HASSANI. 2008. Analyse des flavonoïdes présents dans les feuilles du lentisque par les méthodes chromatographiques. Biotech 2008, XIes Journées Scientifiques du réseau « Biotechnologies végétales / Amélioration des plantes et sécurité alimentaire " de l'Agence universitaire de la Francophonie. 30 juin-3 juillet 2008, Agrocampus Rennes, France. Page 46.

HAOULI, A., R. SERIDI, S. DJEMLI AND O. BOURDJIBA. 2015. Contribution to the Analysis of Pistacia lentiscus Extracted Oil. Journal of Agricultural \& Environmental Sciences., 15 (6) : 1075-1081.

HILALI, M., Z. CHARROUF, A. SOULHI, L. HACHIMI AND D. GUILLAUME. 2005. Influence of origin and extraction method on argan oil physico-chemical characteristics and composition. Journal of Agricultural and Food Chemistry, 53 (6) : 2081-2087.

IBANEZ, J. AND A. USUBILlAGA. 2006a. The essential oil of Espeletia schultzii of different altitudinal populations. Flavour Fragrance Journal, 21 (2): 286-289.

IBANEZ, J. AND A. USUBILLAGA. 2006b. Analysis of the essential oil of two different altitudinal populations of Coespeletia moritziana (Sch. Bip.ex Wedd) Cuatrec, Flavour Fragrance Journal, 21 (5): 760-763.

JONES, G.A., T. A. MACALLISTER, A. D. MUIR, K. J. CHENG. 1994. Effect of sainfoin (Onobrychis viciifolia Scop). Condensed tannins on the growth and proteolysis by four strains of ruminal bacterial. Applied Enviromental Microbiology, 60 (4) : 13741378.

KANDJI, N.A. 2001. Etude de la composition chimique et de la qualité d'huiles végétales artisanales consommées au Sénégal. Thèse de
Doctorat en Pharmacie. Université Cheikh Anta Diop, Faculté de médecine, de pharmacie et d'ontostomatologie, Dakar, $66 \mathrm{p}$.

KARLESKIND, A. AND J. P. Wolff. 1992. Manuel des corps gras. Ed: Tech et Doc. 1579p.

KATIRI A, M. BARKAOUI, F. MSANDA AND H. BOUBAKER. 2017. Ethnobotanical Survey of Medicinal Plants Used for the Treatment of Diabetes in the Tizi n' Test Region(Taroudant Province, Morocco). Journal of Pharmacognosy and Natural Products 3(1):130.

LANFER-MARQUEZ, U.M., R. M. C. BARROS AND P. SINNECKER. 2005. Antioxidant activity of chlorophylls and their derivatives. Food Research International, 38 : 885-91.

LANFRANCHI, F.R. (DE), T. M. BUI AND M. GIRARD. 1999. La fabrication d'huile de lentisque (listincu ou Chessa) en Sardaigne. JATBA, Revue d'Ethnobiologie, Vol. 41 (2) : 81-100.

LAZLI, A., M. BELDI, L. GHOURI, AND N. H. NOURI. 2019. Étude ethnobotanique et inventaire des plantes médicinales dans la région de Bougous (Parc National d'El Kala,- Nord-est algérien). Bulletin de la Société Royale des Sciences de Liège, Vol. 88 : $22-43$.

LAZZER, A., M. COSSENTINI, M. KHLIF AND B. KARRAV. 2006. Etude de l'évolution des stérols, des alcools aliphatiques et des pigments de l'huile d'olive au cours du processus de maturation. Journal de la société chimique de Tunisie. 8: 21-32

LONGO, L., A. SCARDINO AND G. VASAPOLLO. 2007. Identification and quantification of anthocyanins in the berries of Pistacia lentiscus L., Phillyrea latifolia L. and Rubia peregrina L.. Innovative Food Science and Emerging Technologies. 8 (3) : 360-4.

MAAMERI-HABIBATNI, Z. 2014 . Pistacia lentiscus L: Evaluation pharmacotoxicologique. Thèse de Doctorat en sciences. Université de Constantine I, Faculté des sciences de la nature et de la vie, Constantine, 102. P.

MARMESAT, S., A. MORALES, J. VELASCO, M. V. RUIZ-MÉNDEZ AND M. C. DOBARGANES. 2009. Relationship between changes in peroxide value and conjugated dienes during oxidation of sunflower oils with different degree of unsaturation. Grasas y Aceites, 60 (2), 155-160.

MEHMOOD, T., A. AHMAD, A. AHMED AND N. KHALID. 2012. Quality evaluation and safety assessment of different cooking oils available in Pakistan. Journal of the Chemical Society of Pakistan, 34 (3): 518-25.

MELENDEZ-MARTINEZ, A. J., I. M. VICARIO, F. J. HEREDIA. 2003. Application of Tristimulus Colorimetry to Estimate the Carotenoids Content in Ultrafrozen Orange Juices. Journal of Agricultural and Food Chemistry 51: 7266.

MERZOUGUI, I. 2015. Caractérisation physicochimique et biochimique d'un extrait de Pistacia Lentiscus et détermination de ses effets sur certains paramètres biologiques. Thèse de doctorat 3ème cycle. Univ. Badji Mokhtar. Annaba. 136p. 
MEZNI, F., A. MAAROUFI, M. MSALLEM, M. BOUSSAID, M. LARBI- KHOUJA AND A. KHALDI. 2012. Fatty acid composition, antioxidant and antibacterial activities of Pistacia lentiscus L. fruit oils. Journal of Medicinal Plants Research, 6 (39) : 5266-5271.

MIARA, M.D., H. BENDIF, M. AIT HAMMOU AND I. TEIXIDOR-TONEU. 2018. Ethnobotanical survey of medicinal plants used by nomadic peoples in the Algerian steppe. Journal of Ethnopharmacology. 219:248-56.

MOYANO, M. J., F. J. HEREDIA AND A. J. MELENDEZ-MARTINEZ. 2010. The Color of Olive Oils: The Pigments and Their Likely Health Benefits and Visual and Instrumental Methods of Analysis. Comprehensive Reviews In Food Science And Food Safety . Vol. 9 : 278-291.

MUKHERJEE, S. AND A. MITRA. 2009. Health effects of palm oil. J Hum Ecol. 26 (3) : 197-203.

NAGAYAMA, K., Y. IWAMURA, T. SHIBATA, I. HIRAYAMA AND T. NAKAMURA. 2002. Bactericidal activity of phlorotannins from the brown alga Ecklonia kurome. Journal of Antimicrobial Chemotherapy, $50: 889-893$.

NEGASH, Y.A., D. E. AMARE AND B. D. BITEW. 2019. Assessment of quality of edible vegetable oils accessed in Gondar City, Northwest Ethiopia. BMC Research Notes, 12, 793.

https://doi.org/10.1186/s13104-019-4831-X

OKECHALU, J. N., M. M. DASHEN, P. M. LAR, B. OKECHALU AND T. GUSHOP. 2011. Microbiological quality and chemical characteristics of palm oil sold within Jos Metropolis. Nigeria: Plateau State.

OLSON, J. A. 1999. Carotenoids and human health. Archivos Latinoamericanos de Nutricion, 49 (1-S), pp. 7-11.

OUSSOU K. R., K. COFFI, G. NATHALIE, Y. SERI, K. GERARD, D. MIREILLE, T. N. YAO, F. GILLES AND C. JEAN-CLAUDE. 2004. Activités antibactériennes des huiles essentielles de trois plantes aromatiques de Côte d'Ivoire, Comptes rendus de Chimie, 7: 1081-1086.

OUELBANI, R., S. BENSARI, T. N. MOUAS AND D. KHELIFI. 2016. Ethnobotanical investigations on plants used in folk medicine in the regions of Constantine and Mila (Northeast of Algeria). Journal of Ethnopharmacology. 194:196-218.

PALOZZA, P. 2004. Carotenoids and modulation of cancer: molecular targets. Curr Pharmacogenomics 2: $35-45$.

PONCE, A.G., R. FRITZ, C. DEL VALLE AND S. I. ROURA. 2003. Antimicrobial activity of oils on the native microflora of organic Swiss chard. Society of Food Science and Technology (Elsevier). 36: 679684.

RHATTAS, M., A. DOUIRA AND L. ZIDANE. 2016. Étude ethnobotanique des plantes médicinales dans le Parc National de Talassemtane (Rif occidental du Maroc). Journal of Applied Biosciences 97: 9187 9211. http://dx.doi.org/10.4314/jab.v97i1.5
ROSSELL, B. 1993. Measuring resistance to oxidative rancidity Food. International Publisher of Science, Technology and Medicine, 4: 220-225.

SENOUCI, F., A. ABABOU AND M. CHOUIEB. 2019. Ethnobotanical Survey of the Medicinal Plants used in the Southern Mediterranean. Case Study: The Region of Bissa (Northeastern Dahra Mountains, Algeria). Pharmacognosy Journal, 11 (4): 647-659.

TAGURI, T., T. TANAKA AND I. KOUNO 2006. Antibacterial Spectrum of Plant Polyphenols and Extracts Depending upon Hydroxyphenyl Structure. Biology Pharmacology Bulletin, 29 (11): 22262235.

TAHIRI, O. 2008. Caractérisation de l'activité antibactérienne des extraits de Pistacia lentiscus et de Fraxinus angustifolia. Mémoire de Magistere en Biologie Moléculaire. Université A. MIRA de Bejaia.

TASSOU, C.C. AND G.J.E. NYCHAS 1995. Antimicrobial activity of the essential oil of mastic gum (Pistacia lentiscus var. chia) on Gram positive and Gram negative bacteria in broth and in model food system. International Biodeterioration \& Biodegradation 36: 411-420.

TCHIEGANG, C., M. NGO OUM, A. ABOUBAKAR DANDJOUMA AND C. KAPSEU. 2004. Qualité et stabilité de l'huile extraite par pressage des amandes de Ricinodendron heudelotii (Bail.) Pierre ex Pax pendant la conservation à température ambiante, Journal of Food Engeneering, 62, 69-77.

TKACHEV, A.V., E. A. KOROLYUK AND W. LETCHAMO. 2006. Chemical screening of volatile oil-bearing flora of Siberia IX. Variations in chemical composition of the essential oil of Hetero pappus altaicus Willd. (Novopokr.) growing wild at different altitudes of Altai Region, Russia. Journal of Essential Oil Research, 18: 149-151

TRABELSI, H., O. A. CHERIF, F. SAKOUHI, P. VILLENEUVE, J. RENAUD, N. BAROUH, S. BOUKHCHINA AND P. MAYER. 2012. Total lipid content, fatty acids and 4-desmethylsterols accumulation in developing fruit of Pistacia lentiscus L. growing wild in Tunisia. Journal of Food Chemistry, 131: 434-440.

VOUTILAINEN S., T. NURMI, J. MURSU AND T. H. RISSANEN. 2006. Carotenoids and cardiovascular health. American Journal of Clinical Nutrition, 83: 1265-71.

WANG L, GAZIANO JM, NORKUS EP, BURING JE, SESSO HD. 2008. Associations of plasma carotenoids with risk factors and biomarkers related to cardiovascular disease in middleaged and older women. American Journal of Clinical Nutrition, 88 : 747-54.

ZAHIR, I., S. ELAZAOUI, M. CHAKOURI AND B. NAOUER. 2020. Etude ethnobotanique de tetraclinis articulate dans la region de Béni MellalKhénifra. Ethnobotany Research \& Applications. 19: 36 (2020). 


\title{
الخصائص الفيزيائية والكيميائية والأنشطة المضادة للبكتريا والفطريات لزيت الفستق العدس في شمال شرق الجزائر
}

\author{
منصف بلدي 1"، عبد النور بوشكر 12 ، راضية جلول 1و أمال العزلي 1 \\ 1 مخبر البيئه الوظيفية والنطورية، قسم البيولوجيا، كلية علوم الطبيعة والحياة، جامعة الثاذلي بن جديد،

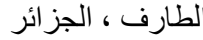 \\ 2 مخبر حفظ الأر اضي الرطبة ـ جامعة قالمة ـ الجزائر
}

الملخص العربـــي

تهدف هذه الدر اسة إلى المساهمة في تثمين واستغلال Pistacia lentiscus ، المسمى محليا بالضرو، و وهي شجيرة تنمو في الأحر اش في مناخات البحر

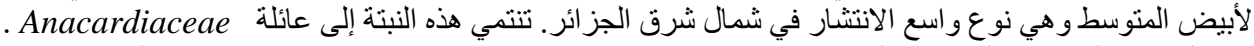

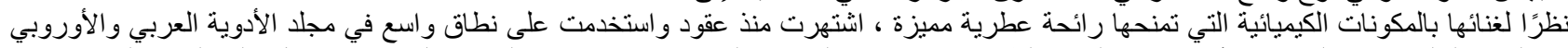

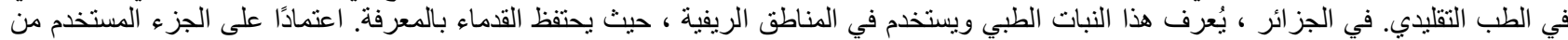

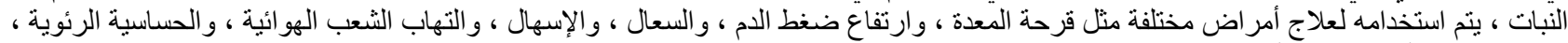

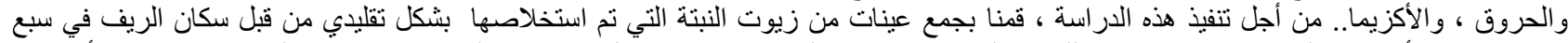

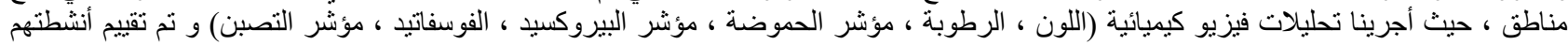

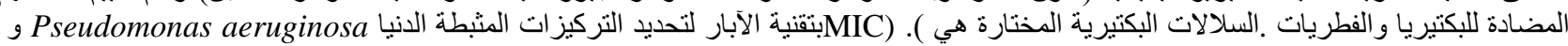

Staphylococcus aureus و Klebsiella pneumonia

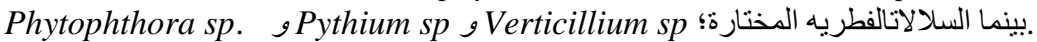

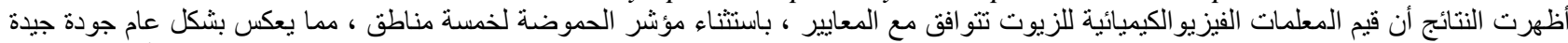

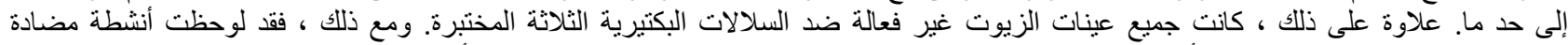

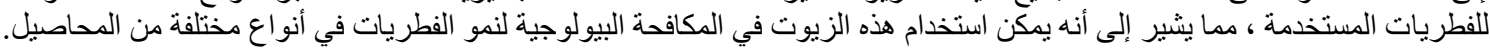

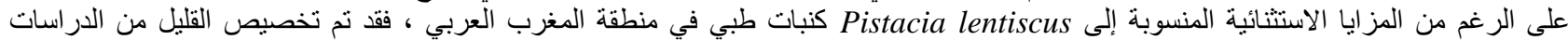

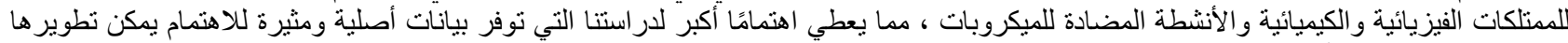
وتعميقها في المستقبل الأبحاث. 